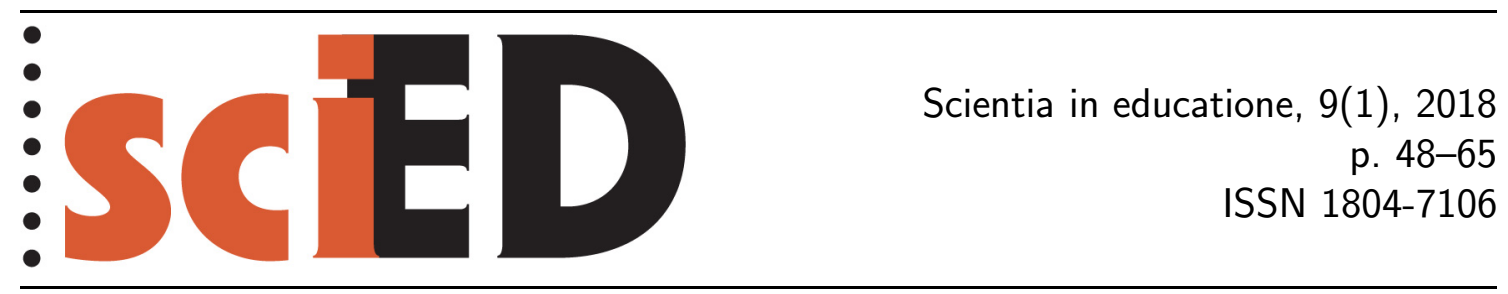

\title{
Dovednost studentů učitelství biologie aplikovat teorii didaktických situaci při přípravě na výuku
}

\author{
Kateřina Jančaříková, Lenka Pavlasová
}

\begin{abstract}
Abstrakt
Příspěvek se zabývá teorií didaktických situací formulovanou pro didaktiku matematiky a možnostmi jejího využití v didaktice biologie. Prezentovaný výzkum zkoumá dovednost studentů učitelství biologie aplikovat danou teorii při př́pravě na výuku. Tato dovednost byla posuzována na základě vytvořených př́prav na výuku a na základě otázek, které si studenti při př́pravách kladli a které písemně zaznamenávali. Data byla analyzována kvalitativně. Studenti dokázali tuto teorii velmi dobře aplikovat již při prvním seznámení s ní. Z tohoto důvodu ji doporučujeme $\mathrm{k}$ zařazení do kurzů didaktiky biologie.

Klíčová slova: teorie didaktických situací, vysokoškolská pedagogika, didaktika biologie.

\section{Skill of Future Biology Teachers to Apply Theory of Didactical Situations in Preparation for Teaching}

\begin{abstract}
The paper deals with the theory of didactic situations formulated for the didactics of mathematics and possibilities of its use in the didactics of biology. Research presented in this paper examines the ability of pre-service biology teachers to apply aforementioned theory in preparation for teaching. This skill was evaluated on the basis of the students' written preparation for teaching and with regard to the questions they solved during this process and they wrote down. The obtained data was analysed by qualitative approach. The results show that the students were able to apply this theory appropriately even at their first encounter with it. For this reason we recommend it to be incorporated into courses of didactics of biology.
\end{abstract}

Key words: theory of didactical situations, university pedagogy, didactics of biology. 
Všichni učitelé, obecní i oboroví didaktici, stále hledají efektivní metody a formy vyučování. Nejinak je tomu i v oblasti výuky př́rodních věd, které se potýkají s klesajícím zájmem o jejich studium (White Wolf Consulting, 2009; Papáček, 2010). Aktivizace žáků a zvýšení jejich motivace je cílem mnoha v současnosti probíhajících výzkumů (např. Velayutham, Aldridge \& Fraser, 2011; Janštová, 2016). Značná pozornost je v oborově didaktické literatuře věnována badatelsky-orientované výuce (Petr, 2014; Papáček et al., 2015), projektové výuce (napřr. Rusek, 2015), exkurzím (Braund \& Reiss, 2004; Pavlasová et al., 2015), metodě kritického myšlení a dalším. Tyto výukové postupy vyžadují specifické přípravy na hodinu (výuku), se kterými by se měli studenti učitelství seznámit při svém přípravném studiu. Vytvoření přípravy na hodinu s různým zaměřením je obvykle jedním ze základních výstupů samostatné práce studenta didaktiky. Vyučující zpravidla kontrolují jenom výstupy (písemné přípravy), které spojují se skupinovou diskusí nebo s individuálním rozhovorem se studentem. V našem příspěvku jsme se zaměřily nejen na výsledek, ale i na samotný proces přípravy na výuku, při které měli studenti použít jim do té doby neznámou teorii didaktických situací.

Teorie didaktických situací (TDS) je známa z publikací didaktiků matematiky a výukové praxe učitelů matematiky (Brousseau, 1997; Brousseau \& Sarrazy, 2002; Nováková, 2013; Novotná et al., 2006). Jedná se o ucelenou, konstruktivisticko-strukturalistickou, didaktickou teorii, která chápe vzdělávací proces jako posloupnost různých situací vedoucích $\mathrm{k}$ modifikacím v chování žáků typickém pro získání nových znalostí (Novotná et al., 2006). Dosud nebyla př́liš často aplikována v jiných předmětech než v matematice, a nebyl tak využit její potenciál, který podle našeho názoru nesporně má. Jejím využitím ve vyučování biologie se zabývá Christian Orange (2007).

Cílem tohoto př́íspěvku je krátce představit teorii didaktických situací učitelům a didaktikům biologie a seznámit je s výzkumným šetřením, ve kterém byla zjištována dovednost studentů učitelství biologie aplikovat tuto teorii při přípravě na výuku.

\section{TEORIE DIDAKTICKÝCH SITUACÍ}

Teorii didaktických situací představil didaktikům na počátku 70. let dvacátého století francouzský učitel matematiky a didaktik matematiky Guy Brousseau. Vzdělávací proces chápe Brousseau jako postupně probíhající přirozené a ř́zené situace. Přirozené situace nazývá „nedidaktickými“ a dále se jim nevěnuje, ačkoli respektuje skutečnost, že vzdělávání probíhá i neřízeně, tedy nezávisle na učiteli (Brousseau, 1997). Ř́zené situace nazývá didaktickými situacemi. Definuje je jako záměrné, učitelem řízené, vzdělávání. Prostředí, ve kterém se vyučovací proces odehrává, nazývá Brousseau didaktické prostředí (milieu). Milieu definuje jako prostředí, které zahrnuje všechny vlivy, jež žáka ovlivňují.

Podle teorie didaktických situací se řízené vzdělávání rozděluje do tří fází. Didaktické situaci předchází specifická příprava na vyučování, kterou Brousseau nazývá a priori analýza (a priori $=$ fr. předem). Po nich následuje specifický dvoufázový rozbor, který Brousseau nazývá posteriori analýza (postérieur=fr. později, obr. 1).

\subsection{A priori ANALÝZA}

A priori analýza je vlastně specifickou přípravou na vyučovací hodinu. Obsahuje přípravu vlastních činností, soubory úloh, her, otázek, ale - a v tom vidíme její 

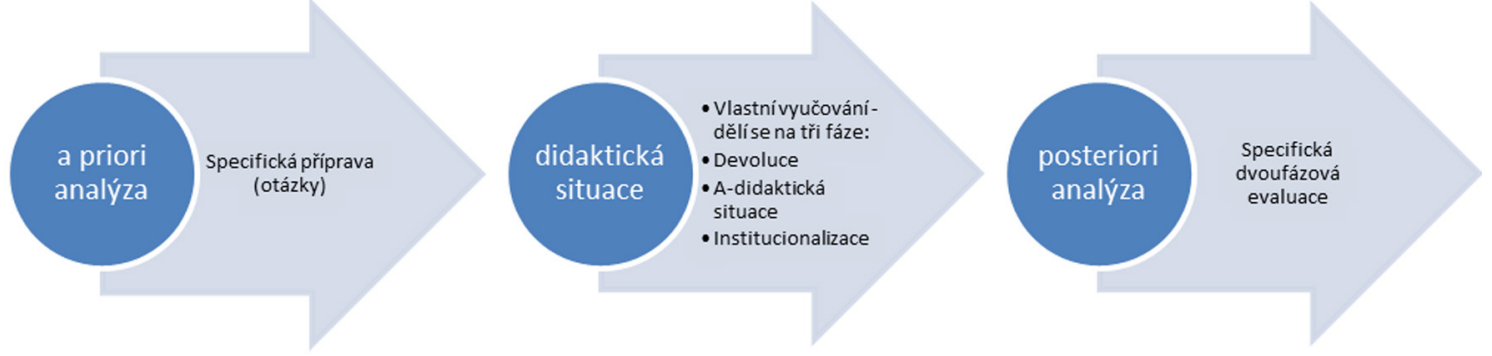

Obr. 1: Tři fáze řízeného vzdělávání podle Brousseaua

potenciál - obsahuje také rozbor problémů, které mohou nastat při vyučovací hodině, což v běžné přípravě obvykle zahrnuto nebývá (Nováková, 2013). Učitel si tedy před vyučováním záměrně klade otázky: „Na co se mne mohou žáci zeptat?“, „S čím si mohou daný pojem či přírodninu splést?" atd. Speciální zřetel je třeba klást především na možné epistemologické překážky ${ }^{1}$, které mohou žákům bránit při práci (Brousseau, 1989). Podle Brousseaua (1986/1998: s. 49) je najít dobré otázky stejně důležité jako hledání odpovědí nebo vyřešení problémů.

Při a priori analýze musí vyučující vzít v úvahu i prostředí, v rámci kterého bude celá následující a-didaktická situace probíhat. Ptá se a promýšlí následující otázky: „Čím mohou být žáci v daném prostředí vyrušeni?“, "Co prostředí nabízí pro podporu výuky?" Aplikováno do didaktiky přírodních věd např. „Jaká zviŕrata v daném prostředí budeme moci pozorovat nebo chytit?", „Jak naši aktivitu ovlivní počasí?"“

\subsection{DidAKTICKÁ SituaCE}

Didaktická situace je taková situace, v rámci které se vyučující snaží žáky naučit zvolené téma a vést je k osvojení si vybraných znalostí a dovedností. Odehrávat se může ve vyučovací hodině ve tř́iě, v rámci laboratorních cvičení, projektu nebo exkurze. Brousseau (1997) uvádí tři fáze didaktické situace: devoluci, a-didaktickou situaci a institucionalizaci.

Devoluce (dévolution $=$ fr. decentralizace, tj. přesunutí funkcí a kompetencí na žáky) je úvodní část vyučovací hodiny, ve které vyučující vysvětluje žákům úkol či jim představuje problém, poskytne jim materiály nebo informace, které budou moci v rámci následné práce využivat, a předává jim zodpovědnost za jeho řešení.

Devoluce je způsob jednání, kterým učitel vede žáka k přijetí zodpovědnosti za (a-didaktickou) vyučovací situaci nebo za problémovou situaci a při kterém sám přijímá důsledky tohoto předání zodpovědnosti.

(Brousseau \& Novotná, 2012: s. 56)

A-didaktická situace je fází, při které žáci pracují na zadaném úkolu. Je to základ celého procesu učení. Proto je jí třeba věnovat největší pozornost při přípravě na vyučovací hodinu (v a priori analýze); vyučující musí přemýšlet o tom, co by během a-didaktické situace mělo, mohlo nebo nemělo proběhnout či nastat, přemýšlet o organizaci výuky žáků atd. (Brousseau, 1997; Brousseau \& Sarrazy, 2002). Jedním

\footnotetext{
${ }^{1}$ Epistemologická překážka (v orig. obstacle épistémologique) je nepravdivý nebo nepřesný poznatek, který je nutné překonat, aby bylo dosaženo vyššího (pravdivějšího) poznání. Příkladem může být výrok „producenty v ekosystému jsou zelené rostliny“, který bylo třeba doplnit slovem především. Jinak řečeno epistemologická překážka je překážka, která brání v poznání. V užším pojetí je to poznatek, který si žák osvojil v jednom kontextu, kde tento poznatek platí, ale protože ho zobecnil, přenesl do jiného kontextu, ve kterém neplatí, brání v dosažení skutečného poznání (Jančaříková, 2015).
} 
z předpokladi̊, jak zefektivnit samostatnou práci žáků je dle Brousseaua: a) zvýšit vnitřní motivaci žáka, b) omezit ruchy z prostředí čili nevyučovat v exteriéru, ale v interiéru, který žákovi neposkytuje nežádoucí vzruchy (cit. podle Orange, 2007). Orange (2007) ale podotýká, že při aplikaci teorie do výuky př́rodních věd není možné prostředí (přírodu) chápat jako rušivý element, že má pro didaktiku přírodních věd jiný význam než pro didaktiku matematiky. Odměnou za usilovnou práci je žákovi radost z poznávání a pochopení (aha! efekt) a společenské uznání, nejčastěji respekt spolužáků či učitele.

Poslední fází celého procesu je institucionalizace (promyšlené zakončení vyučovací hodiny). Na začátku fáze institucionalizace vyučující ukončuje samostatnou práci žáků, přebírá iniciativu a pomáhá žákům dosažené poznatky utřídit, formalizovat tak, aby je dokázali dále používat, a to i v jiném kontextu. V rámci institucionalizace vyučující shrne to, co bylo cílem práce a čeho bylo dosaženo.

Joshua a Dupin (1989) popisují, že optimální je, když dochází k „vědecké debatě ve tř́idě“. Fáze institucionalizace je důležitá jak pro žáky, tak pro vyučujícího. Uvědomí-li si žák „oficiálně“, co je předmětem poznatku, a uvědomí-li si učitel, že se žák něčemu naučil, jedná se o velice důležitou a významnou fázi didaktického procesu (Brousseau, 2012; cit. z Jančařík, 2013). K poznání vím, co jsem se naučil, může pochopitelně docházet i spontánně, ale zásah či spíše vhodné usměrnění ze strany učitele urychluje proces poznávání a zvyšuje sebevědomí žáka.

Důležité je, aby učitel dokázal naplánovat a vést vyučovací hodinu tak, aby na institucionalizaci zůstalo dost času.

\subsection{Posteriori ANALÝZA}

Posteriori analýza (Brousseau, 1997) je speciálním, systematickým vyhodnocením vyučovací hodiny (v kontextu popisované teorie a-didaktické situace). Je více promyšlená a strukturovaná než reflexe či vyhodnocování, které učitelé na našich školách běžně provádějí. Probíhá ve dvou fázích. První fáze posteriori analýzy následuje neprodleně po hodině, lekci či aktivitě a slouží k zaznamenání postř̌ehů a detailů z celé didaktické situace do pedagogova deníku. Druhá fáze následuje s časovým odstupem a slouží k celkovému vyhodnocení průběhu výuky. V rámci posteriori analýzy se hodnotí také to, jak se vlastní průběh didaktické situace shodoval s a priori analýzou (Novotná, 2003).

\section{CÍL VÝZKUMU A VÝZKUMNÉ OTÁZKY}

Výzkum byl zaměřen na první fázi teorie didaktických situací, a priori analýzu, tedy na př́pravu na výuku. Cílem bylo sledovat proces př́pravy na výuku u studentů posledního ročníku navazujícího magisterského studia učitelství biologie. Prvním sledovaným aspektem bylo pojetí vlastní přípravy na výuku z hlediska zvolených výukových činností, možností spolupráce žáků, časové dotace na výukové aktivity a navržené pomůcky ve všech třech fázích didaktické situace. Z navrženého pojetí výuky, prezentace př́ipravy a navazující diskuse bylo možné usoudit, zda studenti TDS pochopili. Druhým aspektem, který pomohl objasnit proces přípravy na výuku, byly otázky, které si studenti během př́ípravy kladli a které řešili. Stanovily jsme tyto výzkumné otázky:

1. Jaké je pojetí př́ípravy studentů na výuku z hlediska aplikace teorie didaktických situací? Pochopili princip teorie didaktických situací?

2. Které otázky si studenti kladli během př́pravy na výuku vycházející z teorie didaktických situací? 


\section{Metodologie}

\section{1 ÚČASTNÍCI VÝZKUMU}

Účastníky výzkumu byli prezenční studenti učitelství biologie pro 2. a 3. stupeň ( $n=20 ; 18$ žen, 2 muži) ve 2 . ročníku navazujícího magisterského studia, kteří již absolvovali didaktickou př́pravu i pedagogické praxe. Můžeme je tedy považovat za studenty na konci učitelského studia. Účastníci byli vybráni na základě dostupnosti, výzkumu se zúčastnil celý ročník prezenčního studia v daném akademickém roce.

\subsection{ZADÁNÍ ÚKOLU A SBĚR DAT}

Sběr dat proběhl v průběhu dvouhodinového výukového celku, který měl následující strukturu. Nejprve autorky článku představily studentům teorii didaktických situací s oporou PowerPointové prezentace (pro studenty nové téma) a ponechaly studentům prostor pro dotazy. Poté byl zadán úkol pro skupinovou práci, kdy měli studenti vytvořit př́pravu na jednu vyučovací hodinu, ve které měli využít teorii didaktických situací. Téma bylo zadáno jednotně: Obojživelníci pro 2. stupeň základní školy. Studentům byly dány $\mathrm{k}$ dispozici učebnice př́rodopisu z různých nakladatelství a mohli využít internet k vyhledávání obrázků, schémat, pracovních listů a dalších výukových materiáli̊. Žádné další informace typu rozsah učiva nebo tematické zaměření učiva jim záměrně poskytnuty nebyly. Studenti pracovali v pěti skupinách po 3-5 členech. Do skupin se rozdělili spontánně. Čtyři skupiny tvořily ženy, v páté skupině pracovali dva muži a jedna žena. Na vytvoření přípravy měli 30 minut. Během tvorby přípravy si měli zároveň písemně zaznamenávat všechny otázky, které je napadly. Poté následovala slovní prezentace jednotlivých skupin, během které si autorky činily zápisky, které použily posléze ke komentování výsledků.

\subsection{ANALÝZA DAT}

Analyzována byla následující data: písemně zaznamenané otázky, které si studenti kladli v průběhu přípravy na hodinu, a vlastní písemné přípravy na hodinu. Vyhodnocení dat probíhalo v obou případech kvalitativně. Popis skupin a jejich výstupů byl doplněn z poznámek autorek pořízených v průběhu prezentace skupin. Otázky zapsané skupinami studentů (označeny $1-5$, viz oddíl 4.1 ) byly tř́́děny do kategorií. Kategorie byly zpočátku vytvářeny ad hoc, při reanalýze byly zpřesňovány (Švaříček \& Šdová, 2007), viz tab. 4. Přípravy na hodiny jsou popsány slovně a jejich vybrané parametry (viz tab. 1-3) porovnány.

\section{VÝSLEDKY A JEJICH INTERPRETACE}

\subsection{POPIS SKUPIN A JEJICH VÝSTUPŮ}

\subsubsection{SKUPINA 1}

Studenti v této skupině projevovali značnou responsibilitu k žákům a také chut se naučit nové metodě. $\mathrm{K}$ př́pravě přistupovali s iniciativou a hravě. Žákovské aktivitě přenechali hodně prostoru. Popisují, že se jim v rámci skupiny dobře spolupracovalo a neměli protichůdné názory. Hodinu pojali jako motivační a jejím cílem byl úvod 
do tématu obojživelníci. Časové dotace na jednotlivé části hodiny nestanovili, pouze u počáteční hry uvádějí, že by měla trvat 10-15 minut.

Do fáze devoluce zařadili motivační pohybovou hru (typu „Bludiště“). Žáci pracovali ve skupinách a měli vyřešit na základě indicií zadaný úkol. Do skupin byli rozděleni na základě losování barevných kartiček a každý zastával určitou roli (zapisovatel, sběratel) přidělenou učitelem podle jejich schopností.

Ve fázi a-didaktická situace nechali žáky pracovat opět ve skupinách. Úkolem žákovských skupin bylo popsat obojživelníky z obrazové dokumentace promítané dataprojektorem a vyvodit jejich obecné znaky (činnost byla zahájena brainstormingem). Jako modelové organismy zvolili ze skupiny ocasatých obojživelníků mloka a ze skupiny bezocasých žábu (ropuchu). Časovou dotaci neuvedli.

Ve fázi institucionalizace následovalo doplnění chybějících informací a zápis učitele na tabuli. Pro opakování navrhli dvě možnosti podle času, který jim na konci hodiny zbyde: a) technika „kahoot“, když zbyde více času, b) opakování za pomoci dotazování učitele při nedostatku času. Hodinu by zakončili společnou otevřenou otázkou „Co jste si dnes zapamatovali?“, která by posloužila k závěrečné reflexi.

Při přípravě vypsali devět otázek, z toho ovšem jen tři charakterem odpovídaly otázkám kladeným v a priori analýze. Zajímavé je, že se tyto žádané otázky objevily na konci jejich výčtu, jako by se postupně dostávali k tomu, jak takové otázky vlastně formulovat. Důležité je, že na všechny otázky nabízejí zároveň i odpověd' (vlastní řešení problému). Otázky zasahují široké spektrum problémů a ukazují, že skupina o výuce uvažuje komplexně. Tři otázky se týkají obecných aspektů výuky (práce ve skupinách a formy zápisu na tabuli). Dále zde najdeme po jedné otázce řešící: pojetí výuky („Udělat př́pravu systematicky nebo ekologicky?“), motivaci („Jak žáky motivovat a uvést do tématu?"“), rozsah učiva („Jedná se pouze o úvod do tématu?“), časová dotace („Délka hry?)“, technické problémy („Půjde technika?“) a předpokládané miskoncepce žáků („S čím si mohou splést mloka skvrnitého?“).

\subsubsection{SKUPINA 2}

Studenti v této skupině projevili opakovaně snahu mít všechno pod kontrolou a velice neradi ji ztráceli či přenechávali. K přípravě přistupovali s chutí a pečlivě. Popisují, že se jim v rámci skupiny nespolupracovalo dobře a že měli protichůdné názory na uspořádání hodiny. Nejpodrobněji naplánovali časování vyučovací hodiny (rozdělili ji do 7 celků po 5-10 minutách) a její struktura připomíná strukturu klasické vyučovací hodiny. Na začátku navrhli opakování z minulých hodin - téma ryby, které probíhá slovně - učitel se ptá na hlavní znaky této skupiny obratlovců a připravuje tak žáky (patrně) na pozdější porovnání se znaky nově probíraných obojživelníků.

Na začátek vyučovací hodiny naplánovali zjištění znalostí žáků z látky, kterou ten den plánovali probrat, a teprve následně jim učivo přednesli. Jejich skupina jako jediná nenaplánovala sdělení cíle vyučovací hodiny na začátku vyučování. Na závěr naplánovali opakování formou testu.

Fáze devoluce začíná promítnutím obrázku mloka skvrnitého. Učitel chce po žácích uvést jeho název a jeho zařazení do systému (tedy jednoduchou informaci, že se nejedná o rybu, ale o jinou, novou skupinu obratlovců). Po uvedení nového názvu „obojživelníci“ je tento pojem učitelem vysvětlen a žáci jsou dotázáni na další druhy, které již znají. V této aktivitě žáci sami přijdou na téma hodiny, byt její cíl není explicitně sdělen. Následuje výklad.

Ve fázi a-didaktická situace nechali žáky pracovat samostatně. Jejich úkolem bylo vyplnit tabulku v pracovním listu (charakteristické znaky obojživelníků). A učitel 
záhy vstupuje do samostatné práce a kontroluje ji (na celou akci i s kontrolou správnosti učitelem vyčlenili jen 5 minut). Nekladou si ovšem otázku, co dělat v př́padě, že žák vyplní tabulku nesprávně. Součástí kontroly má být i zopakování a shrnutí (patrně provedené učitelem).

Poté následuje ihned přechod k dalšímu tématu, rozmnožování obojživelníki̊. Probíhá pomocí výkladu, při kterém žáci popisují obrázek v pracovním sešitu. Učitel poté obrázek ještě promítne a téma si společně zopakují.

Následuje intermezzo (vybočuje z TDS), ve kterém učitel demonstruje žákům ukázky žáby, čolka, mloka a pulce v lihovém nálevu. Žáci sedí v lavicích a chodí postupně ke katedře (byla zmíněna obava, aby preparáty nepoškodili, kdyby je měli na lavicích). Mají určovat o jaké druhy (a vývojová stadia) se jedná a učitel je kontroluje. Naplánováno na 5 minut, což je s největší pravděpodobností nedostatečné.

Ve fázi institucionalizace probíhá kontrola pomocí testu s 8 otázkami z probrané látky. Následuje společná kontrola a zadání domácího úkolu (referát na zástupce z ocasatých a bezocasých obojživelníků za podpory PP prezentace). Naplánováno na 10 minut.

Při přípravě vypsali 13 otázek. Všechny mají jednoho společného jmenovatele: obavu z průběhu výuky. Na žádnou otázku neodpovídají, nenabízejí řešení ani vysvětlení. Nejvíce otázek (5) se týká obavy ze selhání učitele, z jeho nedostatečných znalostí a špatného výběru výukových aktivit („Nebudou žáci zbytečně zvídaví?“, „Jak reagovat na přehnanou snahu diskutovat na probírané téma?", „Co se žáky s SPU?“). Čtyřri otázky mají souvislost s obavou, zda budou žáci dostatečně aktivní („Budou se hlásit všichni žáci během opakování v úvodu hodiny?“), dvě otázky řeší kázeň žáků („Nebudou žáci při pohybu po třídě (myšleno při přesunu k preparátům) prŕliš hluční?"), jedna řeší, zda budou žáci učivo znát a v jedné se obávají technických problémů (fungující dataprojektor).

\subsubsection{SKUPinA 3}

Studenti ve skupině uvedli, že téma obojživelníci vyžaduje minimálně 2 vyučovací hodiny. Př́prava na výuku obsahuje jenom první z nich v souladu se zadáním úkolu. Na začátku př́ipravy uvádějí kognitivní cíle hodiny.

Do fáze devoluce zařadili opakování z minulé hodiny (hravou formou), kdy použili kř́žovku na předchozí výukové téma ryby s tajenkou skrývající název nového tématu a výklad. Křřžovka má mít i motivační funkci, výklad obsahuje úvodní informace o tř́idě obojživelníků. Žákům jsou současně rozdány nakopírované poznámky.

Ve fázi a-didaktická situace nechali žáky pracovat ve čtyřech skupinách. Skupinám rozdělili úkoly (dvě skupiny zpracovávaly bezocasé obojživelníky, další dvě skupiny ocasaté obojživelníky) s tím, že mají zadané živočichy za pomoci učebnice charakterizovat a představit vybrané zástupce ostatním skupinám. Věnovali pozornost roli učitele v této fázi (sleduje a podporuje zapojení všech žáki̊). Nebáli se nechat žákům prostor na samostatnou práci (na a-didaktickou situaci naplánovali 15 minut).

Ve fázi institucionalizace naplánovali prezentaci výsledků samostatné práce žáků kontrolovanou učitelem doprovázenou zápisem poznámek do sešitů. Na závěr učitel provede krátké shrnutí a informuje žáky o tom, co se bude probírat na další hodině.

Při přípravě vypsali 14 otázek k vyučovací hodině a 16 otázek, které mohli žáci položit při práci s textem učebnice. Otázky k vyučovací hodině se nesou také převážně v duchu obav, ale skupina není zcela bezradná, k některým otázkám připojuje 
i řešení nebo alespoň vysvětlení přičiny problému uvedeného v otázce. Nejčastěji je zmiňována obava z nedostatečné kázně a nedostatečného plnění povinností žáky (5 př́padů, např. „rušení žákư“, „ztráta zápisků“, „nebudou poslouchat“), obava z nedostatečných znalostí a dovedností žáků (3 případy, např. „nepochopí zadání křrižovky“, „neporozumí textu“, „nebudou znát látku z předchozích hodin“). Shodně vždy dvě otázky byly věnovány obavám z malé aktivity žáků („Ve skupině nebudou pracovat všichni.“), ze selhání učitele kvůli špatnému naplánování hodiny („Může se stát, že se nestihne zopakovat.") a obecným aspektům výuky (dělení do skupin, počet žáků ve třídě). Otázky žáků při práci s textem (16) jsou uvedeny zvlášt́ a týkají se bez výjimky obsahu učiva. Svědčí o tom, že se skupina nad učivem zamýšlela opravdu podrobně.

\subsubsection{SKUPINA 4}

V úvodu členové skupiny uvádějí, že učivo navazuje na téma ryby a formulují dva kognitivní cíle.

Do fáze devoluce zařadili krátkou informaci o tom, jak bude vyučovací hodina probíhat a o jejích cílech. Naplánovali krátkou devoluci následovanou 10minutovou motivační aktivitou, kdy pomocí obrázků na interaktivní tabuli určovali zástupce obojživelníků (celkem 13 minut).

Ve fázi a-didaktická situace nechali žáky pracovat ve dvojicích. Dvojice doplňovaly text $\mathrm{s}$ chybějícími slovy (srovnávali znaky obojživelníků a ryb a popisovali stavbu těla žáby). Potřebné informace se žáci dovídají z pracovního listu připraveného učitelem. Studenti si připravili podpůrnou variantu alá scaffolding ${ }^{2}$ pro situaci, že žáci nebudou schopni chybějící slova sami doplnit (promítnutí nabídky pojmů). Nebáli se nechat žákům prostor na samostatnou práci (na a-didaktickou situaci naplánovali 22 minut).

Ve fázi institucionalizace naplánovali zhodnocení a shrnutí bez další specifikace (15 minut).

Při př́ipravě vypsali 13 otázek k vyučovací hodině, které rozdělili do dvou skupin: 4 k úvodní fázi a $9 \mathrm{k}$ samostatné práci. Většina otázek (11) byla formulována jako dotazy, které lze očekávat od žáků, a týkaly se konkrétního učiva. Pouze dvě otázky se týkaly problémů, které mohou nastat při vyučování. V obou př́ípadech se obávali, že žáci nebudou mít dostatečné znalosti nebo dovednosti. V jednom případě sami nabízejí řešení ( „Pokud by byl problém s doplněním textu, promítnu žákům nabídku slov k doplnění.“), ve druhé situaci řešení není uvedeno („Žáci dosud neviděli žádného mloka nebo čolka.").

\subsubsection{SKUPINA 5}

Studenti uvádějí, že měli problém se shodnout na tom, jak má vyučovací hodina TDS probíhat. Výsledná práce je kompromisem. V této skupině studenti počítali (možná až př́liš) s velkými vstupními znalostmi žáků. Přímo zmiňují i hlavní afektivní cíl výuky - vytvoření kladného vztahu žáků k obojživelníkům. A hlavní kognitivní cíle: vysvětlení pojmu obojživelníci, charakteristika skupiny a hlavní zástupci. Aktivity směřující k jejich naplnění se prolínají celou výukou.

\footnotetext{
${ }^{2}$ Scaffolding (někdy používán český ekvivalent lešení) je označení pro podporu poskytovanou dítěti či žákovi při řešení problémů tak, aby dosáhli požadovaných cílů. Jedná se tedy o souhrnné označení metod, které pomáhají překlenout rozpětí, které popisuje zóna nejbližšího vývoje (Jančařík, 2013).
} 
Do fáze devoluce zařadili hru řízenou učitelem a diskusi, která má vést žáky k uvědomění si toho, že obojživelníky znají, jsou to zajímavé organismy a „není nutné z nich mít hrůzu“. Hra využívá slovní přesmyčky (čerpáno z pracovního sešitu k učebnici nakladatelství Fraus) a fotografie zviŕat.

Ve fázi a-didaktická situace učitel využívá práci s textem obsahujícím informace o jednotlivých druzích obojživelníků. Práce je podpořena návodnou tabulkou, ve které budou nadepsány znaky obojživelníků, kterých by si měli všímat. Pracují ve skupinách, jejich úkolem je vyvodit, co mají obojživelníci společné. Časovou dotaci neurčili.

Ve fázi institucionalizace naplánovali shrnutí kolektivní formou na základě tabulky (kognitivní cíle) a reflexi afektivního cíle pomocí hledání odpovědí na otázky "Co nejhoršího nám můžou udělat?" a „Co je na nich zajímavé?".

Při př́pravě uvedli pouze dvě otázky, obě i s řešením. První problém předpokládají s porozuměním textu, který by vyřešili vytvořením výkonově srovnatelných skupin a průběžnou kontrolou práce učitelem. Druhý očekávaný problém, nezájem o téma, by se snažili eliminovat použitím atraktivních fotografií a úvodním luštěním přesmyček, případně i ukázkou živých exemplářù.

\subsection{KOMPARACE PŘÍPRAV (a priori ANALÝZ) JEDNOTLIVÝCH SKUPIN}

Tři fáze příprav na výuky zkoumaných skupin studentů jsme mezi sebou porovnávaly podle vybraných kritérií (výukové činnosti, spolupráce žáků, časová dotace, pomůcky), viz tab. 1-3. Toto porovnání bylo východiskem pro vyhodnocení první z výzkumných otázek.

Tab. 1: Porovnání vybraných parametrů v prŕípravách skupin na fázi devoluce

\begin{tabular}{|c|c|c|c|c|c|}
\hline Parametr & Skupina 1 & Skupina 2 & Skupina 3 & Skupina 4 & Skupina 5 \\
\hline $\begin{array}{l}\text { Výukové } \\
\text { činnosti }\end{array}$ & $\begin{array}{l}\text { didaktická } \\
\text { hra }\end{array}$ & $\begin{array}{l}\text { dialog, } \\
\text { výklad }\end{array}$ & $\begin{array}{l}\text { didaktická } \\
\text { hra, výklad }\end{array}$ & $\begin{array}{l}\text { poznávání } \\
\text { zástupců }\end{array}$ & $\begin{array}{l}\text { didaktická } \\
\text { hra, diskuse }\end{array}$ \\
\hline Spolupráce žáků & skupiny & samostatně & samostatně & hromadně & hromadně \\
\hline Časová dotace & 10-15 min. & 15-20 min. & 15 min. & 13 min. & neuvedeno \\
\hline Pomůcky & $\begin{array}{l}\text { různé indicie } \\
\text { (obrázky, } \\
\text { př́írodniny } \\
\text { apod.) }\end{array}$ & $\begin{array}{l}\text { obrázek } \\
\text { mloka }\end{array}$ & $\begin{array}{l}\text { křížovka, } \\
\text { písemné } \\
\text { poznámky }\end{array}$ & $\begin{array}{l}\text { obrázky se } \\
\text { zástupci na } \\
\text { interaktivní } \\
\text { tabuli }\end{array}$ & $\begin{array}{l}\text { slovní } \\
\text { přesmyčky, } \\
\text { obrázky } \\
\text { zástupco̊ }\end{array}$ \\
\hline
\end{tabular}

Ve fázi devoluce (tedy činnosti učitele před samostatnou prací žáků) bylo ve třech př́padech zjištěno použití didaktické hry, shodně ve dvou př́padech použití výkladu a dialogických metod (dialog, diskuse) a v jednom př́́padu poznávání organismů. Ve dvou případech byla navržena samostatná práce, $\mathrm{v}$ dalších dvou případech probíhala výuka hromadně a jednou ve skupinách. Časová dotace vyhrazená na devoluci se pohybovala mezi 10-20 minutami. Ve čtyřech případech by studenti použili obrázky zástupců v tištěné nebo elektronické formě, jedna skupina navrhovala i využití přírodnin. Další pomůcky byly textového charakteru (kř́̌̌žovka, slovní přesmyčky, písemné poznámky). Zjištování, co o daném tématu žáci vědí, se v této fázi objevuje u tř́i skupin. 
Tab. 2: Porovnání vybraných parametrů v přípravách skupin na fázi a-didaktická situace

\begin{tabular}{|c|c|c|c|c|c|}
\hline Parametr & Skupina 1 & Skupina 2 & Skupina 3 & Skupina 4 & Skupina 5 \\
\hline $\begin{array}{l}\text { Výukové } \\
\text { činnosti }\end{array}$ & $\begin{array}{l}\text { brainstorm., } \\
\text { popis } \\
\text { zástupců } \\
\text { podle } \\
\text { obrázku } \\
\text { a vyvození } \\
\text { char. znaků }\end{array}$ & $\begin{array}{l}\text { vyplnění } \\
\text { tabulky } \\
\text { (char. } \\
\text { znaky), její } \\
\text { kontrola } \\
\text { a shrnutí }\end{array}$ & $\begin{array}{l}\text { vyhledávání } \\
\text { informací } \\
\text { v textu } \\
\text { (char. znaky } \\
\text { a zástupci), } \\
\text { př́íprava } \\
\text { prezentace }\end{array}$ & $\begin{array}{l}\text { doplňování } \\
\text { textu (char. } \\
\text { znaky) } \\
\text { a popis } \\
\text { obrázku }\end{array}$ & $\begin{array}{l}\text { vyhledávání } \\
\text { info v textu, } \\
\text { vyplňování } \\
\text { tabulky, } \\
\text { vyvození } \\
\text { char. znaků }\end{array}$ \\
\hline $\begin{array}{l}\text { Spolupráce } \\
\text { žáků }\end{array}$ & nách & $\begin{array}{l}\text { samostatná } \\
\text { práce }\end{array}$ & nách & cích & pinách \\
\hline Casová dotace & neuvedeno & $5 \mathrm{~min}$ & $15 \mathrm{~min}$. & $22 \mathrm{~min}$. & neuvedeno \\
\hline Pomůcky & $\begin{array}{l}\text { promítané } \\
\text { obrázky } \\
\text { zástupců }\end{array}$ & pracovní list & učebnice & $\begin{array}{l}\text { pracovní } \\
\text { list }\end{array}$ & $\begin{array}{l}\text { text, tabulka } \\
\text { okopírovaná } \\
\text { z učebnice }\end{array}$ \\
\hline
\end{tabular}

V a-didaktické situaci studenti navrhovali v podstatě shodně jako hlavní činnost aktivity vedoucí $\mathrm{k}$ vyvození charakteristických znaků obojživelníků. Volili $\mathrm{k}$ tomu různé postupy, je z nich však patrná snaha o přenechání aktivity žákům. Jádrem činností byla práce s textovým a obrazovým materiálem (popis obrázku, doplňování tabulky nebo textu, vyhledávání informací v textu, příprava prezentace). Ve čtyřech případech tato činnost byla naplánována ve skupinách nebo dvojicích, v jednom př́padě samostatně. $\mathrm{V}$ prř́padě skupinové práce studenti také uváděli klíč, jakým způsobem by žáky dělili do skupin (losem nebo podle schopností). Casovou rozvahu studenti většinou neuváděli, pokud ano, pohybovala se mezi 15-22 minutami. Pomůckami byla ve dvou př́padech učebnice, ve stejném počtu prř́padů pracovní list, dále obrázky nebo odborný text.

Tab. 3: Porovnání vybraných parametrů v př́pravách skupin na fázi institucionalizace

\begin{tabular}{|c|c|c|c|c|c|}
\hline Parametr & Skupina 1 & Skupina 2 & Skupina 3 & Skupina 4 & Skupina 5 \\
\hline $\begin{array}{l}\text { Výukové } \\
\text { činnosti }\end{array}$ & $\begin{array}{l}\text { doplnění } \\
\text { informací } \\
\text { a zápis, } \\
\text { opakování, } \\
\text { reflexe žáků }\end{array}$ & $\begin{array}{l}\text { test a jeho } \\
\text { kontrola, } \\
\text { zadání } \\
\text { referátu }\end{array}$ & $\begin{array}{l}\text { prezentace } \\
\text { spolužákům, } \\
\text { zápis, shrnutí }\end{array}$ & $\begin{array}{l}\text { zhodnocení, } \\
\text { shrnutí, } \\
\text { doplnění } \\
\text { informací }\end{array}$ & $\begin{array}{l}\text { shrnutí } \\
\text { informací } \\
\text { v tabulce, } \\
\text { reflexe } \\
\text { afektivního } \\
\text { cíle }\end{array}$ \\
\hline $\begin{array}{l}\text { Spolupráce } \\
\text { žáků }\end{array}$ & hromadně & $\begin{array}{l}\text { samostatně, } \\
\text { hromadně }\end{array}$ & $\begin{array}{l}\text { skupiny, } \\
\text { samostatně, } \\
\text { hromadně }\end{array}$ & neuvedeno & hromadně \\
\hline Časová dotace & neuvedena & $10 \mathrm{~min}$. & $15 \mathrm{~min}$. & 15 min. & neuvedena \\
\hline Pomůcky & tabule & test & sešity & neuvedeno & tabulka \\
\hline
\end{tabular}

Fázi institucionalizace studenti pojali jako shrnutí informací, jejich doplnění, zápis do sešitu, opakování, kontrolu znalostí (psaní testu) a žákovskou reflexi. Výuka by již byla převážně vedena hromadně s časovou dotací 10-15 minut. Pomůcky by sloužily k zápisu informací (tabule, tabulka, sešit) nebo ke kontrole znalostí (test). Dále do této fáze bylo zařazeno i zadání domácího úkolu a uvedení informací o další vyučovací hodině. 


\subsection{ZAMĚŘENÍ OTÁZEK KLADENÝCH PŘI PŘÍPRAVĚ}

Studenti vypsali celkem 67 otázek, kterými se zabývali při návrhu výuky (fáze $a$ priori analýza). Nejméně otázek si kladla skupina 5 (2 otázky), nejvíce skupina 3 (30 otázek). Přehled zaměření otázek kladených si studenty při př́ípravě na výuku je uveden v tab. 4.

Tab. 4: Porovnání zaměření kladených otázek při př́ípravě

\begin{tabular}{lccccc}
\hline Zaměření otázky & Skupina 1 & Skupina 2 & Skupina 3 & Skupina 4 & Skupina 5 \\
\hline Vytváření skupin žáků & 2 & - & 2 & - & - \\
\hline Pojetí výuky př́rodopisu & 1 & - & - & - & - \\
\hline Motivace, aktivita žáků & 1 & 4 & 2 & - & 1 \\
\hline Kázeň žáko̊ & - & 2 & 5 & - & - \\
\hline Znalosti, dovednosti žáků & 1 & 1 & 3 & 2 & 1 \\
\hline Selhání učitele & - & 5 & 2 & - & - \\
\hline Učivo & $1^{*}$ & - & $16^{* *}$ & $11^{* *}$ & - \\
\hline Casová dotace & 1 & - & - & - & - \\
\hline Technika & 1 & 1 & - & - & - \\
\hline Jiné & 1 & - & - & - & - \\
\hline Celkem & 9 & 13 & 30 & 13 & 2 \\
\hline
\end{tabular}

* rozsah učiva, ** předpokládané otázky žáků

Mezi nejčastěji kladené otázky patřily dotazy zaměřené na motivaci a aktivitu žáků (celkem u všech skupin 8), na znalosti a dovednosti žáků (8), na kázeň žáků (7) a na obavy ze selhání učitele (7). Způsob, jakým vytvářet skupiny žáků, studenti řešili celkem ve 4 př́padech. Na okraji jejich zájmu je pojetí výuky (systematické versus ekologické), učivo (nepočítáme-li vypsání konkrétních otázek, které by jim mohli klást žáci) a časová dotace jednotlivých činností. Možná to považují za samozřejmost a neřeší to. Ne všechny uvedené otázky se ovšem týkaly přímo aplikace teorie didaktických situací, ale můžeme je považovat za otázky obecnějšího rázu, které se řeší i při jiných způsobech vedení výuky (př. „Půjde technika?“, „Nebudou si psát poznámky.").

\subsection{VYHODNOCENÍ PŘÍPRAV (a priori ANALÝZY) A VÝZKUMNÝCH OTÁZEK}

Studenti ve skupině 1 přesně pochopili, v čem teorie didaktických situací spočívá, př́pravu na výuku řeší komplexně z více hledisek. Skupina 2 jako jediná nedodržela schéma hodiny vycházející ze zásad TDS. Studenti neměli odvahu přenechat žákům více prostoru na vlastní aktivní činnost, projevili velké obavy ze selhání učitele, rozbití pomůcek apod. Naplánovali dva velice krátké úkoly, na kterých žáci pracovali samostatně, ale mezi nimi ovšem učitel záhy přejímá hlavní roli a kontroluje žáky. Celkově na samostatnou práci vychází zhruba 5 minut. Studenti ve skupině 3 velice dobře pochopili zadání a samotnou TDS. Uvedli, že TDS budou v budoucnu využívat. Při prezentaci spontánně zmiňovali problémy, které by mohly při vyučovací hodině nastat. Studenti ve skupině 4 také velice dobře pochopili zadání a samotnou TDS. Jeden ze studentů z této skupiny řekl, že tuto metodu vlastně již instinktivně využívá, protože se při př́ipravě sám sebe ptá, co by mohlo žáky napadnout apod. 
Studenti ve skupině 5 používali terminologii TDS a tázali se např. i na to, jak se „metodou“ bude pracovat žákům, kteří na ni nejsou zvyklí. Uvedli, že jsou rádi, že se s TDS seznámili. Pochopili, že navazuje na teorii konstruktivismu a ptali se, zda je vlastní objevitelství žáků vždy možné. Uvažovali o limitech metody, kdy učitel není vždy schopen zajistit splnění cíle kvůli př́lliš velkému prostoru, který by měl být žákům ponechán. Metodu doporučují střídat s ostatními metodami výuky. Jako jediná skupina pracovali i s předpokládaných strachem žáků z obojživelníků. I když opakovaně použili termín „metoda“, sami uvádějí, že se vlastně o výukovou metodu nejedná.

V první výzkumné otázce jsme řešily, jaké je pojetí přípravy studentů na výuku z hlediska aplikace teorie didaktických situací. Podle níže uvedených shrnujících hodnocení skupin lze konstatovat, že studenti ve čtyřech skupinách pochopili teorii didaktických situací a dokázali ji poměrně dobře aplikovat a využít při vlastní př́ipravě na výuku. Jen jedné skupině dělala aplikace problémy, které pramenily zejména z obavy z poskytnutí prostoru žákům a přenechání jim odpovědnosti za vlastní vzdělávání.

S pojetím příprav na výuku dobře korespondují i otázky, které si studenti v jejich průběhu kladli a dokreslují celkové hodnocení skupin. Skupina 1 uvažovala o výuce komplexně, jejich otázky byly zařazeny do 7 kategorií z celkově 9 identifikovaných (viz tab. 4). Skupina 2 řešila nejčastěji možné selhání učitele, aspekty motivace a aktivizace žáků a kázeň žáků. Tomu odpovídá i jejich př́íprava, kdy zmíněné obavy převážily, a rozhodli se, že budou výuku raději řídit, aby dosáhli cíle, který si určili. Skupina 3 sice také řešila především kázeň žáků, ale obavy z možných kázeňských problémů je neodradily od vyzkoušení si jiného stylu výuky. Skupina 4 se v otázkách zaměřila pouze na znalosti a dovednosti žáků a na problematiku učiva (na otázky, které jim budou žáci pravděpodobně klást), což by mohlo vypadat jednostranně. Nicméně uvažování o výuce muselo být komplexní, o čemž svědčí nejen příprava na výuku, ale i prohlášení jednoho člena skupiny, že intuitivně tento postup sám použivá. Skupina 5 si kladla nejméně otázek. Patrně proto, že přirozeně všechny další otázky rovnou spolu vyřešili, a proto jim nepřipadalo důležité je zapisovat. Skupina jako jediná byla schopna i teoretického uvažování o TDS a hodnocení jejich kladů a záporů.

Druhá výzkumná otázka se věnovala rozboru otázek, které si studenti kladli během přípravy na výuku vycházející z teorie didaktických situací. Bylo identifikováno 9 témat, na které byly otázky zaměřeny (tab. 4). Každá skupina ale řešila jen některá témata (v rozmezí od 2 do 7 ). I když jsme primárně nepředpokládaly, že bude hrát roli i počet kladených otázek, ukazuje se, že čím více otázek k TDS (nepočítáme otázky, které pravděpodobně budou klást žáci), tím větší nejistota (skupina 2 a 3) a tím horší aplikace v př́pravě na výuku (skupina 2). To je vlastně logické zajímavé pro další výzkumy.

\section{DisKUSE}

\subsection{MOŽNOSTI VYUŽÍVÁNí TEORIE DIDAKTICKÝCH SITUACÍ V PŘÍRODOVĚDNÉM VZDĚLÁVÁNÍ}

Teorie didaktických situací vychází z pedagogického konstruktivismu a strukturalismu a pracuje s obdobnými cíli a způsoby práce s žákem jako badatelsky-orientované vyučování nebo vyučování rozvíjející kritické myšlení (zvýšení motivace, aha! efekt, induktivní postupy apod.). I když byla původně navržena pro výuku mate- 
matiky, domníváme se, že je velice dobře využitelná i při výuce biologie/přírodních věd. Při bližším seznámení s ní jsme si uvědomily, že se v mnohém potkává s běžnou praxí při vyučování biologie na školách a pochopitelně také s teoretickým zázemím, tedy s didaktikou biologie i didaktikou obecnou, a že nabízí velké možnosti pro zefektivnění výuky biologii.

Pochopení teorie didaktických situací není snadné, protože je to teorie dynamická, která i když vznikla před 30 lety, stále prochází vývojem (Orange, 2007). Na druhou stranu je to vlastně pozitivum, protože teorie neustrnula, ale stále se snaží vycházet vstříc měnícím se nárokům jak žáků, tak pedagogů.

V poslední době se objevila celá řada inovací didaktiky biologie, které ale obvykle vycházejí z nestandardních časových dotací (exkurze, projektové vyučování) a i když bezesporu přinášejí zajímavé možnosti - přece jen je zřejmé, že je učitelé nemohou pravidelně využívat. Teorie didaktických situací věnuje pozornost běžné vyučovací hodině o obvyklém rozsahu 45 minut, tedy nejběžnějšímu vyučovacímu celku, což považujeme za její velký klad.

Dalším nesporným kladem je její srozumitelnost - učitelé jí velice rychle porozumí, protože vychází z obvyklých postupů, které vhodně vylepšuje (většina učitelů si dělá přípravu na vyučování, TDS je učí, jak to dělat lépe). Naproti tomu v současné době populární oblíbená metoda badatelsky orientovaného učení (Papáček, 2010) je pro mnohé učitele jako celek obtížně uchopitelná. Opakovaně se setkáváme s tím, že si z ní vybírají jen jednu, pro žáky nejatraktivnější, část - sběr dat a ostatní části, bez kterých ovšem nemá takový efekt, vynechávají (Činčera et al., 2016; Škoda \& Doulík, 2013).

Teorie didaktických situací velmi dobře koresponduje s Altmannovými didaktickými zásadami pro výuku biologie, např. konkrétně pracuje se zásadami uvědomělosti, aktivnosti a spojením teorie s praxí (Altmann, 1975; Pavlasová, 2014).

Jediným sporným bodem, ve kterém je třeba teorii didaktických situacích pro výuku biologie upravit, je pojetí prostředí. V didaktice biologie má totiž vyučování venku, pod širým nebem, nezastupitelné místo (např. Altmann, 1975; Řehák, 1967; Pavlasová, 2014), kdežto v TDS je vnější prostředí chápáno jako rušivý element (napřr. Orange, 2007).

Na skutečnost, že prostředí hraje velkou roli při vytváření asociací a zpevňování reakcí na podněty (stimuly), upozornili behavioristé. Odměna i trest může totiž přicházet z prostředí, a to naprosto nezávisle na učiteli či trenérovi; často v rozporu s jeho vưlí či hodnocením a nepozorovaně (Jančaříková, 2015). To pochopitelně může vyučování (a proces zapamatování si faktů) v jisté fázi narušovat a je zřejmé, že v prostředí na podněty chudém dochází $\mathrm{k}$ nežádoucím odměnám (odměnám z prostředí) minimálně. Na druhou stranu z pestrého prostředí přichází celá řada podnětů, které poskytují tzv. informální vzdělání (Strejčková, 2005). Italský pedagog Loris Malaguzzi (1920-1994) také chápe prostředí pozitivně a dokonce mu přisuzuje roli třetího učitele. Prvními učiteli jsou v tomto konceptu myšleni rodiče (a rodina vůbec), druhými profesionální učitelé a učitelky a třetím učitelem je prostředí (Malaguzzi, 1994).

\subsection{APlikACE TEORIE VE STUdENTSKÝCH PŘíPRAVÁCH NA VÝUKU}

Studenti se celkem dobře vyrovnali s úkolem připravit vyučovací hodinu na téma Obojživelníci. Správně upozornili (respondenti ze skupiny 3), že téma Obojživelníci 
vyžaduje minimálně dvě vyučovací hodiny. Na začátku přípravy uvádějí kognitivní cíle hodiny (skupiny 1, 3, 4,5) a jedna skupina také cíle afektivní (skupina 5) - jako jeden z cílů vytyčili, aby žáci neměli z obojživelníků strach.

Studenti se až na jednu skupinu nezabývali otázkou, zda zvolit tzv. „ekologický“ nebo systematický přístup k pojetí tématu. Skupina 1 obě možnosti zvažovala a zvolila si systematické pojetí, což i konkrétně uvedla. Ostatní skupiny tento problém vůbec neřešily, ale podle charakteru jejich příprav je zřejmé, že si také volily systematickou výuku. Tato volba nebyla překvapivá, protože vycházela ze zadání úkolu, tj. vytvoření přípravy zaměřené na konkrétní taxon.

Studenti také museli rozhodnout, které organismy do výuky zařadí a které organismy budou sloužit jako modelové organismy. Většinou to řešili zařazením více druhů organismů, dbali na zastoupení ocasatých i bezocasých obojživelníků, i když každý v jiné fázi hodiny. Celkově tam ale neopominuli obě skupiny zařadit. Skupina 1 volila ropuchu a mloka, skupina 2 zvolila pro počáteční aktivitu mloka; v další části hodiny by pracovali se žábou, mlokem a čolkem konzervovaným v etanolu; skupina 3 zmiňuje aktivitu zaměřenou na obě skupiny obojživelníků bez konkrétních zástupců; skupina 4 pracuje s více zástupci, klíčová část hodiny se zaměřuje na popis těla žáby; skupina 5 výběr zástupců blíže nespecifikovala. S volbou zástupců korespondovala i volba pomůcek, kde převažovaly tištěné nebo elektronické materiály. Jen jedna skupina (č. 1) uvažovala o využití přírodnin ve fázi devoluce, což je poměrně málo. Považujeme to za důležitý signál, že tematice využití přírodnin by bylo potřeba v didaktice biologie věnovat více prostoru, aby se práce s př́rodninami ve školách více rozšírila.

V a-didaktické situaci studenti často volili práci žáků s textem (at̉ už se jedná o text učebnice či odborného článku). Metoda práce s textem je starobylá a stále aktuální. V našich školách ji zavedl Friedrich Eberhard z Rochowa (1734-1805) a je uváděna jako první všeobecně používaná metoda vyučování přírodovědných předmětů na našem území (Schmitt, 2001; Jančaříková, 2015). Naši studenti využívali pro práci s textem především připravené pracovní listy a učebnice či kopie vybraného textu z učebnice.

Teorie didaktických situací pracuje (podobně jako další z konstruktivismu vycházející pedagogické teorie) s vnitřní motivací (Kopřiva et al., 2008). Brousseau píše, že odměnou za usilovnou práci je žákovi radost z poznávání a pochopení (čili de facto aha! efekt) a společenské uznání, nejčastěji respekt spolužáků či učitele (Brousseau, 1997). Naši studenti nabízeli různé motivační aktivity (nejčastěji didaktické hry), ale o potřebě zvnitřněné motivace přímo nepsali. $\mathrm{V}$ jejich př́ipravě se ovšem objevují obavy z nekázně žáků, což je vlastně důsledek jejich nedostatečné vnitřní motivace.

Obdobně je v současné době běžnou metodou přenechání aktivity žákům (v terminologii TDS devoluce), protože různé výzkumy přinesly poznatek, že zapamatování si učiva (at již krátkodobé nebo dlouhodobé) koreluje s časem věnovaným samostatné aktivní práci. Nedostatek autonomie při učení je uváděn jako jedna z příčin klesajícího zájmu žáků o přírodovědná výuková témata (Janík \& Stuchlíková, 2010; Jančaříková \& Mazáčová, 2014). Důraz na aktivitu žáků klade také Skinnerův princip aktivní odpovědi (Jančaříková, 2015). Většina našich studentů (výjimkou byli studenti ze skupiny 2) neměla problém s přenecháním aktivity žákům. V budoucnu by bylo vhodné řešit otázku, kolik z 45minutové časové dotace vyučovací hodiny je optimální přenechat na a-didaktickou fázi. Strach studentů ze skupiny 2 přenechat v hodině aktivitu žákům je z tohoto úhlu pohledu rizikový a bylo by vhodné se jím dále zabývat (zjistit jeho příčiny a hledat cesty, jak ho eliminovat). 
Fáze institucionalizace koresponduje s Altmannovou zásadou uvědomělosti (Altmann, 1975) nebo také s Montessori metodou, která s uvědoměním si toho, co umím, pracuje již v předškolním věku (Montessori, 1998). Uvědomění si toho, co umím je velice důležité a významné, přesto je institucionalizace nedostatečně oceňována a je vhodné jí věnovat více pozornosti (Jančařík, 2013). Naši studenti si to zdá se uvědomili, protože většina (skupiny $2,3,4)$ zdůraznila vyšší potřebu plánování časové dotace, aby zbylo dostatečné množství času na důležitou závěrečnou reflexi (institucionalizaci), tři skupiny uvedly čas na institucionalizaci, a to 10-15 minut.

U fáze institucionalizace lze také nalézt paralelu s Vygotského konceptem zóny nejbližšího vývoje ${ }^{3}$. Pokud je žákův poznatek učitelem usměrňován a zasazen do širšího rámce - struktury a propojen s dalšími, již dosaženými znalostmi (Vygotský, 1976), je učení efektivnější.

Zarazilo nás, že si nikdo nepoložil otázku, jak ve fázi institucionalizace ověřovat to, že se žáci něco naučili, resp. co se přesně naučili. A zda to vůbec lze. Orange (2007) uvádí, že ověření znalostí (institucionalizace) je nejobtížnější součástí TDS. Očekávaly jsme, že se studenti nad tímto problém budou alespoň okrajově zamýšlet.

Orange (2007) upozorňuje na skutečnost, že učitel využívající teorii didaktických situací má často přehled jen o těch žácích, kteří mají prostor se projevit, např. tak, že dělají „mluvčí“ svým skupinám, a že není z časových důvodů možné, aby věděl o tom, jaké poznatky si osvojil úplně každý žák ve třídě. Ovšem, na základě našich zkušeností se domníváme, že učitel i v rámci teorie didaktických situací může využít různé prostředky a metody, jak zjistit pokrok každého žáka (zadat jim samostatnou práci, pracovní list k vyplnění, test apod.). Studenti ze skupiny 2 psaní testu navrhovali, ale není jisté, zda o ověřování přemýšleli nebo zda test zařadili z jiných důvodi̊.

Zajímavým jevem je to, že na funkční postupy výuky a práce s žáky přicházejí pedagogičtí pracovníci v různých dobách a kulturách také nezávisle na sobě, intuitivně. I my jsme se s ním během naší práce setkaly. Především ve formulaci jednoho z respondentů (ze skupiny 4), že tuto metodu (myšlena a priori analýza) vlastně již instinktivně využivá, protože se při př́pravě sama sebe ptá, co by mohlo žáky napadnout. Nebo další respondenti z téže skupiny (skupina 4) sami přišli na potřebu poskytnout žákům podporu (a popsaly vlastními slovy „scaffolding“), i když se prrímo s tímto pojmem v rámci didaktiky biologie nesetkali. Domníváme se, že taková vyjádření lze chápat jako doklad toho, že je TDS uživatelsky vstřícná navazuje na to, co učitelé běžně ve výuce (konkrétně např. hodnocení po vyučovací hodině) a v přípravě na vyučovací hodinu dělají a s čím mají zkušenosti. Na základě dlouhodobého výzkumu jim k tomu poskytuje značnou teoretickou i metodickou oporu a umožňuje jim zlepšovat se. Vždy je lepší využít toho, co učitelé dělají a ukázat jim, jak to vylepšit než říci, že dělají všechno špatně a učit je zcela novým postupům, jak to dělají některé jiné školy. Zajímavé by bylo zjištovat, jaké míry předpokládaná shoda v chápání pojmů dosahuje nebo zda není pouze iluzorní.

Čtyři z pěti skupin volily pro fázi devoluce skupinovou práci, ale jen dvě skupiny (skupiny 1 a 5) věnovaly pozornost otázce jak žáky do skupin rozřadit (svobodná volba, los). Je třeba konstatovat, že by bylo vhodné studenty seznámit s metodikou tvorby týmů (např. podle Jančaříková \& Scholleová, 2010).

\footnotetext{
${ }^{3}$ Koncept popisuje pozorováním zjištěnou skutečnost, že když se dítě blí̌zí nějaké vývojové etapě, může mu vhodná podpora dospělého pomoci předběhnout spontánní vývoj. Z toho je vyvozen předpoklad, že vhodně řízené učení pomáhá vývoji, urychluje ho (Vygotský, 1976).
} 
Posteriori analýza se svým dvoufázovým hodnocením vyučování jeví především pro začínající učitele jako užitečná. Podobně jsou ostatně u nás koncipovány i souvislé pedagogické praxe, kdy bezprostředně po hodině provede rozbor učitel kmenové třídy (nebo by alespoň měl) a na závěr praxe provádí ještě jednou reflexi s odstupem katedrový garant praxe.

\subsection{OTÁZKY KLADENÉ A ŘEŠENÉ STUDENTY PŘI PŘÍPRAVĚ NA VÝUKU}

Při výzkumu nás nezajímal jen výsledek práce studenti̊, ale chtěly jsme trochu blíže pochopit i proces vlastní tvorby prŕpravy na výuku u budoucích učitelů. Zvolily jsme proto zpo̊sob sběru doplňkových dat, který spočíval v zaznamenávání otázek, jež studenti v průběhu př́pravy řešili. Studenti celkem dobře pochopili, co po nich chceme a vytvořili a zaznamenali celou řadu otázek. Tyto otázky po rozrazení do kategorií ukazují na problémy, kterými se studenti zaobírali (jejich přehled viz tab. 4, oddíl 4.3). Zajímavé jsou četnosti otázek v kategoriích, kdy studenti mají poměrně dobře zafixováno, že při přípravě na hodinu je důležité promyšlení motivace a aktivizace žáků, rozvaha týkající se znalostí a dovedností žáků jak ve smyslu stanovení cíle, tak ve smyslu jeho kontroly. Naopak nejméně pozornosti věnovali obsahu výuky. I když téma výuky bylo dáno, nebyl dán rozsah tématu; volba, počet ani konkrétní druhy zástupců; množství nových pojmů apod. Přitom tyto úvahy jsou důležité právě při přípravě na hodinu.

Proces přemýšlení studentů při řešení problémů a zmapování jejich postupu je v pedagogice obtížně uchopitelné. Písemné nebo audiovizuální zaznamenávání otázek, které si studenti kladou, a jejich následná analýza se jeví být užitečným výzkumným nástrojem.

\subsection{OMEZENÍ VÝZKUMU}

Výzkum byl proveden na poměrně malém vzorku u studentů jednoho ročníku, což musíme mít na paměti, pokud bychom chtěli výsledky zobecňovat. Další možnost ovlivnění spatřujeme $\mathrm{v}$ zadání jednotného tématu př́iprav na výuku (téma Obojživelníci), které nemusí být pro všechny studenty oblíbené a mohou mít i rozdílné odborné i didaktické znalosti a zkušenosti s tímto učivem. Rozdílné odborné znalosti jsme se snažily vykompenzovat nabídkou na využití učebnic a pracovních sešitů. Lze se jen domnívat, zda by aplikace teorie didaktických situací byla u některých skupin úspěšnější, pokud by si zvolili sami své oblíbené téma. Tuto skutečnost žádný ze studentů sice nenaznačoval, ale ovlivnění celkového výsledku práce studentů nelze zcela vyloučit.

\section{ZÁVĚR}

V příspěvku jsme stručně představily teorii didaktických situací G. Brousseaua a popsaly provedené šetření se studenty posledního ročníku učitelství biologie pro 2 . a 3. stupeň ve 2 . ročníku navazujícího magisterského studia, kteří již absolvovali veškerou didaktickou př́pravu i pedagogické praxe. Studenti dokázali velmi uspokojivě použít tuto teorii při př́ipravě na výuku, což dává naději, že by ji byli schopni použít i při vlastní výuce. Na základě našich zkušeností se domníváme, že teorie didaktických situací má pro výuku biologie značný potenciál. Proto by jí měli oboroví didaktici věnovat pozornost. Jejími klady jsou: a) skutečnost, že se zaměřuje 
na obvyklou vyučovací hodinu s časovou dotací 45 minut, b) srozumitelnost, c) intuitivnost při použití, d) přirozené využití reflektivního cyklu. Doporučujeme tuto teorii zařadit do obsahu kurzů vysokoškolské př́pravy budoucích učitelů biologie a ostatních přírodních věd, a to optimálně v základním oborově didaktickém kurzu před první souvislou praxí ve škole.

\section{PODĚKOVÁNí}

Výzkum byl podpořen programy Progres Q17 Příprava učitele a učitelská profese $v$ kontextu vědy a výzkumu a Progres Q16 Environmentálni výzkum. Autorky dále děkují prof. RNDr. Jarmile Novotné, CSc., za cenné konzultace.

\section{LITERATURA}

Altmann, A. (1974). Úvod do didaktiky biologie. Praha: SPN.

Altmann, A. (1975). Metody a zásady ve výuce biologii. Praha: SPN.

Braund, M. \& Reiss, M. (2004). The nature of learning science outside the classroom. In M. Braund \& M. Reiss (Eds.), Learning Science Outside The Classroom (1-12). New York: Routledge Falmer.

Brousseau, G. (1997). Theory of Didactical situations in mathematics. Dordrecht: Kluwer Academic Publishers.

Brousseau, G. \& Novotná, J. (2012). Úvod do teorie didaktických situací v matematice. Praha: Univerzita Karlova, Pedagogická fakulta.

Brousseau, G. \& Sarrazy, B. (2002). Glossaire de quelques concepts de la théorie des situations didactiques en mathématiques. Bordeaux: DAEST, Université Bordeaux 2.

Činčera, J. \& Jančaříková, K. et al. (2016). Environmentální výchova z pohledu učitelů. Brno: BEZK; Masarykova univerzita; Agentura Koniklec.

Jančařík, A. (2013). Vybrané teorie učeni a jejich projekce do využíání ICT ve výuce matematiky. Praha: UK v Praze, Pedagogická fakulta.

Jančaříková, K. (2015). Didaktické př́stupy k přirodovědnému vzdělávání předškolních dětí a mlaď̌ích žákio. Praha: Univerzita Karlova v Praze, Pedagogická fakulta.

Jančaříková, K. \& Scholleová, H. (2010). Methodology for team member selection for the need of work in course of daily and distance learning education. In th International Conference Efficiency and Responsibility in Education (137-145). Praha: ČZU.

Janštová, V. (2016). Vliv praktické výuky na motivaci žáků středních škol ke studiu biologie. Dostupné z https://is.cuni.cz/webapps/zzp/detail/120124.

Joshua, S. \& Dupin, J. J. (1989). Représentations et modélisations: le "débat scientifique" dans la classe et l'apprentissage de la physique. Berne: Peter Lang.

Malaguzzi, L. (1994). The Bill of Three Rights Innovations in Early Education. The International Reggio Exchange, 2(1). Dostupné z http://resourcelists.roehampton.ac.uk.

Montessori, M. (1998). Tajuplné dětství. Praha: Nakladatelství světových pedagogických směrů.

Nováková, H. (2013). Analýza a priori jako součást přípravy učitele na výuku. Scientia in educatione, $4(2), 20-51$.

Novotná, J. (2003). Ukázky analýzy a priori pro slovní úlohy. In P. Dvořák \& J. Herman (Eds.), Sbornik z Jك̌DS Vrabcov, jaro 2003 (31-54). Praha: UK PedF. 
Novotná, J., Pelantová, A., Hrabáková, H. \& Krátká, M. (2006). Př́prava a analýza didaktických situací. Praha: Společnost učitelů matematiky.

Orange, Ch. (2007). Quel Milieu pour l'apprentissage par problématisation en sciences de la vie et de la terre? Éducation et didactique, 1(2), 37-56.

Papáček, M. (2010). Badatelsky orientované přírodovědné vyučování cesta pro biologické vzdělávání generací Y, Z a alfa?. Scientia in educatione, 1(1), 33-49.

Papáček, M., Ćížková, V., Kubiatko, M., Petr, J. \& Závodská, R. (2015). Didaktika biologie: didaktika v rekonstrukci. In I. Stuchlíková \& T. Janík (Eds.), Oborové didaktiky: vývoj - stav - perspektivy (225-257). Brno: Masarykova univerzita.

Pavlasová, L. \& Hrouda, L. et al. (2015). Př́rodovědné exkurze ve školní praxi. Praha: UK PedF.

Pavlasová, L. (2014). Přehled didaktiky biologie. Praha: UK PedF.

Petr, J. (2014). Možnosti využití úloh z biologické olympiády ve výuce př́rodopisu a biologie: inspirace pro badatelsky orientované vyučování. České Budějovice: JČU.

Rusek, M. (Ed.) (2015). Projektové vyučování v př́rodovědných předmětech XIII. Praha: UK PedF.

Řehák, B. (1967). Vyučování biologii na základni devítileté škole a střední všeobecné škole: Př́spěvek k didaktice biologie. Praha: Svoboda.

Schmitt, H. (2001). Vernunft fürs Volk. Friedrich Eberhard von Rochow 1734-1805 im Aufbruch Preußens. Berlin: Henschel.

Strejčková, E. (Ed.). (2005). Děti, aby byly a žily. Praha: MŽP ČR.

Škoda, J. \& Doulík, P. (2013). Inquiry-based Science Education - módní vlna nebo naděje pro obrodu přírodovědného vzdělávání? In J. Duchovičová, Z. Babulicová \& H. Zelená (Eds.), Pedagogické a psychologické aspekty edukacie (10-19). Nitra: Pedagogická fakulta UKF.

Švařiček, R. \& Šed’ová, K. (2007). Kvalitativní výzkum v pedagogických vědách: pravidla hry. Praha: Portál.

Velayutham, S., Aldridge, J. \& Fraser, B. (2011). Development and validation of an instrument to measure students' motivation and self-regulation in science learning. International Journal of Science Education, 33(15), 2159-2179.

Vygotskij, L. S. (1976). Vývoj vyššich psychických funkcí. 1. vyd. Praha: SPN.

White Wolf Consulting. (2009). Důvody nezájmu žáků o př́rodovědné a technické obory. Dostupné z http://www.generacey.cz/uploads/akce_a_aktuality/pardubicky_kraj/

Duvody_nezajmu_zaku.pdf.

KATEŘINA JANČǍ̌íKOVÁ, katerina.jancarikova@pedf.cuni.cz

Univerzita Karlova, Pedagogická fakulta

Katedra biologie a environmentálních studií

M. Rettigové 4, Praha 1, Čská republika

LEnKa PAVlasová, lenka.pavlasova@pedf.cuni.cz

Univerzita Karlova, Pedagogická fakulta

Katedra biologie a environmentálních studií

M. Rettigové 4, Praha 1, Česká republika 